\title{
Competence of Security Officers in the Management of National Examinations in Secondary Schools in Eastern Province, Kenya
}

\author{
George M. Muthaa', Peter K. Muriungi' ${ }^{2}$, Eunice Kagendo Njue $^{3}$ \\ ${ }^{1}$ Department of Education, Chuka University, Chuka, Kenya \\ ${ }^{2}$ Department of Arts \& Humanities, Chuka University, Chuka, Kenya \\ ${ }^{3}$ Principal Ikuu Girls High School, Chuka, Kenya \\ Email: gmuthaa@yahoo.com
}

Received 1 April 2014; revised 2 October 2014; accepted 15 October 2014

Copyright (C) 2014 by authors and Scientific Research Publishing Inc.

This work is licensed under the Creative Commons Attribution International License (CC BY). http://creativecommons.org/licenses/by/4.0/

c) (i) Open Access

\begin{abstract}
Examinations provide discriminatory criteria for individuals and evaluate whether educational goals are being achieved. To guarantee equity, fair evaluation must be devoid of all malpractices. The study was motivated by the continued incidences of examination irregularities despite the policies put in place by KNEC. A sample size of 120 security officers was used for the study. The study was conducted using descriptive survey research design. Validity of the research instrument was ascertained by experts in research from Chuka University, while the reliability of instruments was determined using Cronbach's coefficient alpha method. The study established that majority of the security officers were not oriented on examinations management. The researcher recommends that security officers should be training on examinations management and their role expectations.
\end{abstract}

\section{Keywords}

Competence, Security Officers, Management, National Examinations

\section{Introduction}

Education in every sense is one of the fundamental factors of development, Shecham, 1987 [1]; Chiromo, 2005 [2]. It raises people's productivity and creativity and promotes entrepreneurship and technological advances, Chiromo, 2005 [2]. In addition education plays a crucial role in securing economic and social progress and im- 
proving income distribution, Bogonko, 1992 [3]. This shows the critical role that education plays in individuals and society at large which gives a justification on the public interest and investment in education.

Evaluation in the education process provides the means of finding out whether education objectives are being attained, Wheeler, 1997 [4]. Formal testing provides base-line information for this evaluation, Afolayan, 1985 [5]. According to Nevo, 1995 [6], evaluation in education has also come to be viewed by different scholars as providing information for decision makers, the systematic investigation of the worth or merit of some object and an act of collecting systematic information regarding the nature and quality of educational objects. Evaluation should therefore be carefully designed and undertaken in a manner that it ensures fairness and objectivity on the outcome of the process.

The Kenya National Examination Council conducts the examinations, evaluates the candidates, issues mark sheets and publishes the results, Ingolo, 2009 [7]. KNEC also constantly re-evaluates the curriculum and the test system through research and processing of statistical data, Ingolo, 2009 [7]. KNEC has set rules and regulations which set equivalent conditions for the examinations so that there is fairness for all those taking the examinations, GOK, 2003 [8]. This is because examinations provide discriminatory criteria for individuals and society in the allocation of scarce opportunities in the society, Yussufu, 1985 [9]. Concerns on fairness of the examination process gave impetus to the current study.

In Kenya, examinations have been marred with malpractices over the years despite the policies put in place for administration, Gicheru, 2005 [10]. Examination malpractice in Kenya has attained a frightening proportion and the malpractices are sophisticated and institutionalized, Kithuka, 2004 [11]. Efforts by government administration and stakeholders in the educational sector to curtail the ugly trend have not yielded any fruit, Kithuka, 2004 [11]. The nature of examination malpractice has resulted in high turnover of incompetent graduates by institutions of higher learning, Aullo, 2004 [12]. Examination malpractice has long graduated from the normal peeping at neighbors' work, using key points notes or text books or copying on sheets of papers referred to as "microchips", or copying on desks also known as "desktop publishing" to a more advanced and more organized system of buying question papers from examination bodies or corrupt bank officials entrusted with the safekeeping of the examination question paper, Siringi, 2007 [13]. The new trends that promote examination malpractices were a concern of the current study.

The climax in cheating and exam leakages by use of technology in the Kenya Certificate of Secondary Education (KCSE) has reached fever pitch in Kenya in 2010, MOE, 2010 [14]. In 2008, the KNEC came up with a number of regulations, including the development of the proposed draft legislation on the administration of examinations and banning of mobile phones in the examination room; and in 2009, the examination body reviewed its examinations timetable which saw the scrapping of examinations in the afternoons, KNEC, 2008 [15]. Additional vehicles and security personnel were dispatched to support the administrator of examination, KNEC, 2008 [15]. Moreover, examination papers were collected from KNEC headquarters a day or two before the date of the papers, thus minimizing the risk of examination leakage from months and weeks to days and hours, KNEC, 2008 [15].

Despite the legal framework put in place, examination irregularities have occurred with every release of KCSE results, which is due to examination malpractices, which can be defined as a deliberate wrong doing contrary to official examination rules designed to place a candidate at an unfair advantage or disadvantage, Afolabi, 1998 [16]. Police and other security offer are required to ensure the security of examination question papers, answer sheets/scripts and other materials from KNEC offices to the distribution centres and ensure that no examination malpractice takes place through the entire examination process, KNEC, 2010 [17]. The current study sought to investigate the competence of security officers in reference to academic qualifications, experience in manning examinations and training.

Examinations provide discriminatory criteria for individuals and society in the allocation of scarce opportunities. In order to guarantee fair evaluation, examinations must be devoid of all malpractices examination malpractice. Cases of examination malpractice have been reported with the release of examinations every year despite the deployment of security officer to oversee the entire process. The current study sought to determine the competence of the security officer's management of the KCSE examination in Eastern Province, Kenya.

\section{Methodology}

The study was conducted using descriptive survey research design. The Descriptive survey research design enabled the researcher to generate data on the competence of security officers in the management of examinations. The 
study was carried out in Eastern Province, Kenya. The study location was chosen because schools in the province have been affected by examination irregularities with the release of examinations every year leading to cancellation of results for affected candidates. The most notable being the cancellation of results for about 76 students in the province involved in examination malpractices in the year 2010.

The target population for this study was 1373 security officers involved in manning examinations. Snowball sampling technique was used to select 120 security personnel, to participate in the study. For purposes of triangulation 360 teachers participated in the study giving a sample size of 480 respondents. Questionnaires were used for data collection. Reliability of the questionnaires was tested using Cronbach's coefficient alpha method. Validity of the instruments was ensured through expert judgment. This study employed descriptive statistics to analyze data. The results were presented using frequency tables, and figures.

\section{Results}

Security officers play a critical role in the management of national examinations. Demographic data of the security officers was obtained under gender and age. A total of 120 security personnel participated in the study. Information on the gender of the security officers was sought. Figure 1 presents the distribution of security officers by gender.

Figure 1 indicates that a large proportion $(83.3 \%$ ) of security officers were males while $16.7 \%$ were females. This shows a big disparity on the gender of security personnel involved in examination management. The imbalance may compromise the extent to which the security personnel can closely monitor the candidates out of the examination room especially when escorting them to the washrooms. Most of the candidates get access to reading materials placed in toilets and washrooms during the examination. Failure by the security officers and invigilators to closely monitor candidates has resulted to examination malpractices since officers of the opposite gender may not examine the toilets to be used by the candidates. Policies should be developed that address gender issues in the appointment of security officers to man different stations. The study sought information on the age of security personnel. The age composition of the respondents is presented in Table 1.

According to the information in Table 1, majority (39.2\%) of the security personnel were below 30 years of age whereas $36.7 \%$ of the security personnel are between $31-40$ years, $22.5 \%$ were in the $41-50$ years age bracket. Only $1.7 \%$ of the respondents were above 51 years of age. Majority of the security personnel involved in manning examination centres are below the age of 30 years.

The objective of the study was to investigate the competence of security officers in manning of examinations in reference to training, academic qualifications, length of service and years involved in the management of

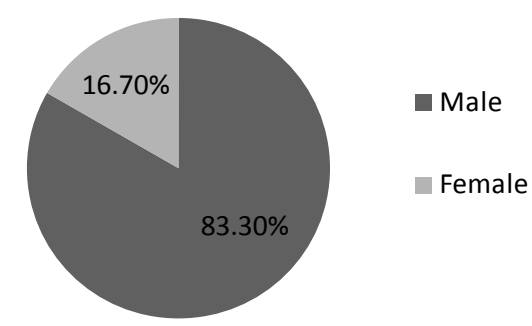

Figure 1. Distribution of security officers by gender.

Table 1. Age distribution of security personnel.

\begin{tabular}{ccc}
\hline Category & Frequency & $\%$ \\
\hline Below 30 years & 47 & 39.2 \\
$31-$ 40 years & 44 & 36.7 \\
$41-50$ years & 27 & 22.5 \\
Above 51 years & 2 & 1.7 \\
Total & 120 & 100.0 \\
\hline
\end{tabular}


KCSE subheadings. The study sought to establish the level of education of the security officers. The findings are presented in Table 2.

Information in Table 2 shows that majority (68.3\%) of the respondents had a secondary school certificate, $17.5 \%$ had certificate qualification while $10.8 \%$ had diploma qualification. Only $0.8 \%$ and $2.5 \%$ of the respondents had primary certificate qualification and university degree qualification respectively. The government should develop policies to guide the academic qualifications necessary for security offers in manning examinations of different levels. It may psychologically be challenging for people with lower academic qualifications to man candidates sitting for examinations at higher rank which may serve to abet cheating.

The study further sought information on the experience of security officers in the management of secondary school examinations. The responses generated from this item are presented in Figure 2.

Information in Figure 2 indicates that a large proportion (36.7\%) of the security officers have an experience of 3 - 4 years in the management of KCSE examination, $25.8 \%$ had served 1 - 2 years while $17.5 \%$ had served 5 - 6 years, $12.5 \%$ had served for over 10 years in management of examinations. Only $7.5 \%$ had served 7 - 9 years in examinations management. This shows that majority of security officers involved in management of examinations had less than 5 years' experience in the management of examinations.

The study sought information on induction of security officers to procedures that entailed examination handling and distribution. One of the KNEC responsibilities is to offer sensitization and briefing of all contracted professionals in handling national examinations. Table 3 presents the findings on induction of security officers regarding examination security procedures.

According to information in Table 3, majority (88.0\%) of the security officers had not been inducted on examination handling procedures while $12.0 \%$ had been inducted. This implies that most of the security officers

\begin{tabular}{ccc} 
Table 2. Academic qualification of security officers. & \\
\hline Academic qualification & Frequency & Percentage \\
\hline Primary & 1 & 0.8 \\
Secondary & 82 & 68.3 \\
Certificate & 21 & 17.5 \\
Diploma & 13 & 10.8 \\
University & 3 & 2.5 \\
Total & 120 & 100.0 \\
\hline
\end{tabular}

Table 3. Security officers' induction on examination security procedures.

\begin{tabular}{cccc}
\hline \multirow{2}{*}{ Item } & \multicolumn{3}{c}{ Responses } \\
\cline { 2 - 4 } & $\mathrm{N}$ & Yes \% & No \% \\
\hline $\begin{array}{c}\text { Have you ever been inducted on security procedures } \\
\text { on examination handling and distribution? }\end{array}$ & 120 & 12.0 & 88.0 \\
\hline
\end{tabular}

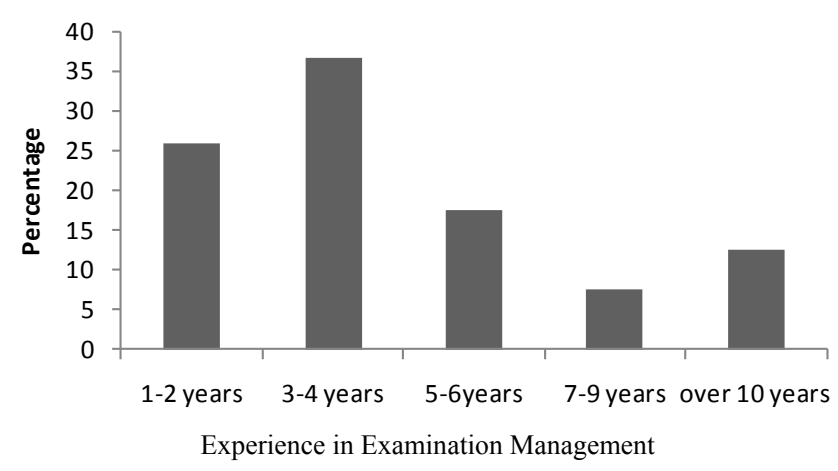

Figure 2. Security officers experience in examination management. 
were not inducted on the procedures in examination handling which may account for increased cases of malpractices. The purpose of induction is to help people involved in examination handling understand the operating regulations and policies involved in management of examinations. Many officers do not receive the level of support they need to execute their mandate, Maunda, 2005 [18].

The objective of the study was to investigate the competence of security officers in the management of examinations. An item was included on the security officers and teachers questionnaires that sought information on the levels of competence in the handling and distribution of examinations. This information is presented in Table 4.

Information in Table 4 indicates that majority of the respondents perceived the security as incompetent and very incompetent at 64.16 and 16.88 respectively in the management of examinations. The researcher sought information on the extent to which the level of competence by security officers contributed to malpractices under the following areas. Table 5 presents finding on this.

Information in Table 5 indicated that security officers' competence contributed to a very great extent and great extent to examinations malpractice in the management of examinations in the distribution centrea/armories and examination centres. These findings are in agreement with observations by Siringi, 2007 [13] that investigations had established that the loopholes occur in the process of transporting of papers, Crooks getting access to the papers at the wee hours as they leave armoires where they smuggle a few questions papers, which are then relayed to candidates.

The researcher sought information on the factors that contributed to incompetence of the security officers in the examinations management. Information generated is presented in Table 6.

Information in Table 6 shows the perception of respondents on the factors that contributed to incompetence among the security officers. Majority of the respondents (41\%) blamed incompetence of the security officers on

Table 4. Level of competence of security officers in examination management.

\begin{tabular}{ccc}
\hline Level of competence & Frequency & Percentage \\
\hline Very competent & 10 & 2.08 \\
Competent & 45 & 9.38 \\
Undecided & 36 & 7.50 \\
Incompetent & 308 & 64.16 \\
Very incompetent & 81 & 16.88 \\
Total & $\mathbf{4 8 0}$ & $\mathbf{1 0 0}$ \\
\hline
\end{tabular}

Table 5. Respondents' perceptions on the contribution of security officers' competence to malpractices.

\begin{tabular}{cccccc}
\hline Handling and distribution Practices & Very great extent & Great extent & No opinion & Small extent & No extent \\
\hline Security at distribution centres/armories & 26.4 & 37.4 & 9.3 & 20.0 \\
Management of security at the examination centres & 22.1 & 36.1 & 10.5 & 23.1 & 2.9 \\
Escorting of examination scripts & 17.5 & 24.4 & 31.2 & 22.2 & 17.2 \\
Suitability of the security officers & 20.8 & 8.6 & 21.7 \\
\hline
\end{tabular}

Table 6. Factors contributing to incompetence among the security officers.

\begin{tabular}{ccc} 
Factors & Frequency & Percentage \\
Lack of training in examination handling & 324 & 188 \\
Lack clear guidelines on the role of security officers & 74 & 23.80 \\
Academic qualifications of security officers & 204 & 9.37 \\
Poor remuneration of during the examination management & $\mathbf{7 9 0}$ & 25.82 \\
Total & $\mathbf{1 0 0}$ \\
\hline
\end{tabular}


the lack of training on examinations management, whereas $23.8 \%$ and $25.8 \%$ blamed the incompetence on unclear roles and poor remuneration of security officers respectively.

\section{Conclusions and Recommendations}

Based on the findings of the study, the following conclusions and recommendations were drawn:

1) Majority of the security officers involved in the management of examinations are of the male gender despite the fact that the number of candidates by gender taking the KCSE is almost equal;

2) A significant number of the security officers engaged to manage examinations had no orientation in examinations management. This is despite of the critical role that they are expected to play in ensuring that the process is free from all forms of malpractices;

3) The lack of training among the security officers on examinations management was the main cause for incompetence which was blamed on the cases of examination malpractices. The government should develop policies that ensure examinations are only manned by security officers trained on examination management which will help feel gaps that contribute in examinations malpractices.

\section{References}

[1] Shecham, I. (1987) School Effectiveness. Printer Publishers, London.

[2] Chiromo, R. (2005) What Can Be Done to the Students Cheating in Examinations.

[3] Bogonko, S.N. (1992) Reflections on Education in East Africa. Oxford University Press, Nairobi.

[4] Wheeler, D.K. (1997) Curriculum Process. Hodder and Stoughton, London.

[5] Afolayan, A. (1985) Language Problems in Curriculum Development and Evaluation in Africa. African Curriculum Organization, Ibadan.

[6] Nevo, D. (1995) School Based Evaluation: A Dialogue for Schools. Elsevier Science Inc., New York.

[7] Ingolo, K. (2009) Maintenance of Standards in KNEC Examination Irregularities. A Paper Presented to Heads of Secondary Schools during the KESSHA Annual National Conference. Whites and Hotel, Mombasa.

[8] Government of Kenya (2003) Laws of Kenya Education Act Chapter 211. Government Printer, Nairobi.

[9] Yussufu, A. (1985) Financing and Security of National Examination. A Paper Presented at the Meeting of Institutions Responsible for Educational Assessment in East and Central Africa. Lilongwe.

[10] Gicheru, W. (2005) Influence of Examination Irregularities in the Management and Administration of Public Examination. KNEC, Nairobi.

[11] Kithuka, M. (2004) Educational Measurement and Evaluation. Egerton University Press, Egerton.

[12] Aullo, P.A. (2004) An Investigation into Factors Contributing to Examination Irregularities in Kenya Certificate of Secondary Education (KCSE) in Eastern Province. University of Nairobi, Nairobi.

[13] Siringi, A. (2007) Raising the Standard up Performance in Public Examination. Proceedings of the WAEC Symposium, Ibadan, August 2007, 45-51.

[14] MOE (2010) Kenya Certificate of Secondary Examination Results Release. MOE, Nairobi.

[15] KNEC (2008) Examination Rules and Regularities. KNEC, Nairobi.

[16] Afolabi, E.R.I. (1998) Validity of Public Examinations, the Environment and Sustainable National Development. Cardinal Crest Ltd., Nairobi.

[17] KNEC (2010) Syllabus and Regulations; Kenya Certificate of Secondary Education. KNEC, Nairobi.

[18] Maunda, A. (2005) Experiences of Examinations Authorities in Controlling Examination Irregularities Kenyan Experience. http://www.tibasrnet/publications 
Scientific Research Publishing (SCIRP) is one of the largest Open Access journal publishers. It is currently publishing more than 200 open access, online, peer-reviewed journals covering a wide range of academic disciplines. SCIRP serves the worldwide academic communities and contributes to the progress and application of science with its publication.

Other selected journals from SCIRP are listed as below. Submit your manuscript to us via either submit@scirp.org or Online Submission Portal.
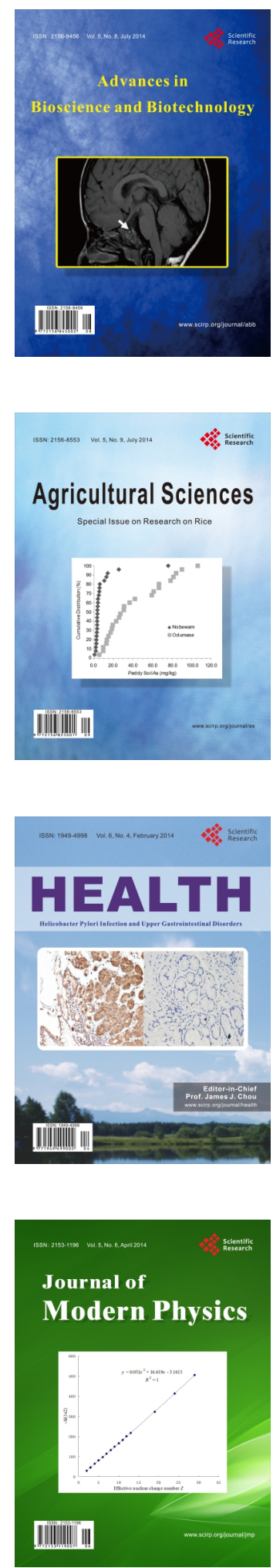
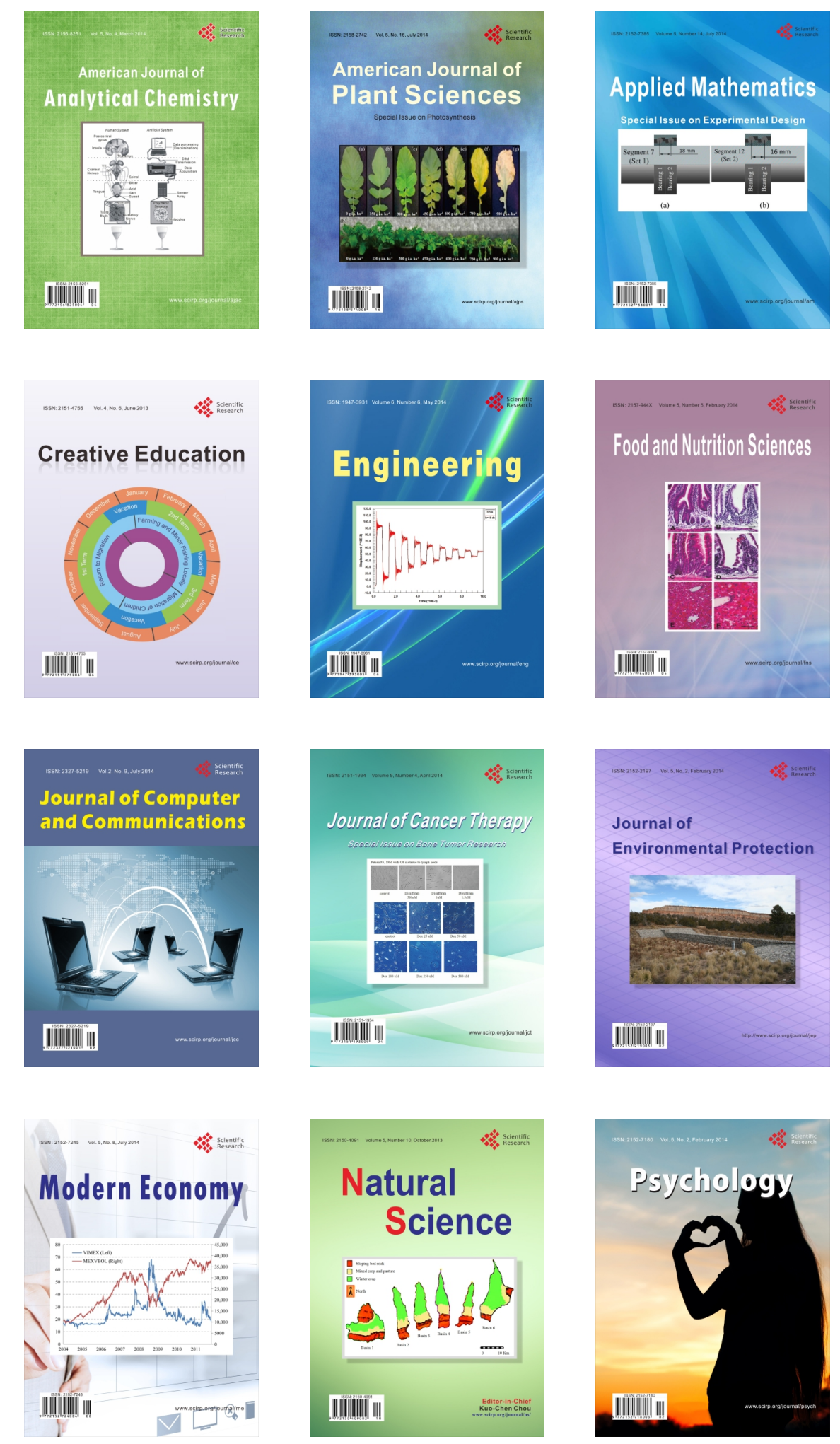